\title{
Analisis Laporan Keuangan Sebagai Alat Untuk Menilai Keberhasilan Dalam Mengelola Modal Kerja Pada PT. Catur Sentosa Adiprana Tbk
}

\author{
Sri Rahayu Lestiari, Yudiana, Hurriyaturrohman \\ Fakultas Ekonomi dan Bisnis Universitas Ibn Khaldun Bogor, Indonesia \\ yudiana@fe.uika-bogor.ac.id
}

\begin{abstract}
A good management of working capital is one of the keys to success in an effort to continue to be active in producing goods and services. Sufficient working capital conditions can make the company operates in accordance with expediency financial according to existing activities and there is no financial difficulties that is experienced by the company.

The purpose of this research is to determine the financial condition that seen from the analysis of financial statements and to find out the conditions of successful management of working capital at PT. Catur Sentosa Adiprana Tbk. Descriptive qualitative method is used in the research. With the calculation of financial ratio analysis and the Altman Z-Score method.

According to the results of the research, that is known from the profitability ratio, it is quite good because the company is still able to manage the profits earned. Based on the calculation of the liquidity ratio shows that the company still has sufficient funds to pay its short-terms liabilities by using current assets even though the calculation results obtained fluctuate. When viewed from the calculation of the ratio of activity conditions of the company in 2015 to 2016 is not effective because of a decrease in the ratio. Based on the analysis of the Z-Score method in 2013-2017 shows the company is in a gray area that allows the company to still be able to improve the financial condition. Meanwhile, in 2015, the company experienced a very significant decline and was in a state of bankruptcy. Thus, the company is still not effective in managing its working capital.
\end{abstract}

Keywords: Working Capital, financial statements, Financial Ratio

\begin{abstract}
ABSTRAK
Pengelolaan modal kerja yang baik adalah salah satu kunci sukses dalam sebuah usaha untuk terus beraktivitas dalam memproduksi barang maupun jasa. Dengan kondisi modal kerja yang cukup, perusahaan beroperasi sesuai dengan kelayakan finansial menurut aktivitas yang ada serta perusahaan tidak mengalami kesulitan keuangan.

Tujuan penelitian ini adalah untuk mengetahui kondisi keuangan yang dilihat dari analisis laporan keuangan dan untuk mengetahui kondisi keberhasilan pengelolaan modal kerja pada PT. Catur Sentosa Adiprana Tbk. Metode penelitian yang digunakan adalah metode deskriptif kualitatif. Dengan perhitungan analisis rasio keuangan dan metode Altman Z-Score.

Berdasarkan hasil penelitian yang diketahui dari rasio profitabilitas, dapat dikatakan cukup baik karena perusahaan masih mampu mengelola laba yang diperoleh. Berdasarkan hasil perhitungan rasio likuiditas menunjukkan bahwa perusahaan masih mempunyai dana yang cukup untuk membayar kewajiban jangka pendeknya dengan menggunakan aktiva lancar walaupun hasil perhitungan yang diperoleh berfluktuatif. Jika dilihat dari perhitungan rasio aktivitas kondisi perusahaan pada tahun 2015 sampai tahun 2016 tidak efektif karena terjadi penurunan rasio. Berdasarkan analisis metode ZScore pada tahun 2013-2017 menunjukkan perusahaan berada pada daerah abu-abu yang memungkinkan perusahaan masih bisa meningkatkan kembali kondisi keuangannya. Namun pada tahun 2015 perusahaan mengalami penurunan yang sangat signifikan dan berada pada kondisi bangkrut. Sehingga, perusahaan dalam mengelola modal kerjanya masih belum efektif.
\end{abstract}

Kata kunci : Modal Kerja, Laporan Keuangan, Rasio Keuangan 


\section{PENDAHULUAN}

Perusahaan adalah organisasi terstruktur yang melakukan kegiatan bisnis meliputi proses manajemen dan produksi yang bertujuan untuk memperoleh keuntungan. Untuk mencapai tujuan tersebut tidaklah mudah, karena suatu perusahaan sering kali menemui berbagai kendala dalam pelaksanaan aktivitasnya. Perkembangan perekonomian dunia saat ini menyebabkan perusahaan menghadapi masalah yang kompleks sehubungan dengan kebutuhan keuangan perusahaan. Oleh karena itu, manajer keuangan dituntut untuk dapat menjalankan manajemen keuangan dengan baik. Hal ini dilakukan agar perusahaan dapat melaksanakan kegiatan operasionalnya dengan lebih efektif dan efisien.

Selain itu, perusahaan juga memerlukan analisis terhadap laporan keuangan untuk mengetahui kemampuan perusahaan dalam mengatasi masalah keuangan, mengetahui posisi keuangan, kinerja keuangan dan kekuatan keuangan yang dimiliki perusahaan.

Analisis laporan keuangan adalah proses penganalisisan atau penyidikan terhadap laporan keuangan, yang terdiri atas neraca dan laporan laba/rugi beserta lampirannya untuk mengetahui posisi keuangan dan tingkat kesehatan perusahaan yang tersusun secara sistematis dengan menggunakan teknik-teknik tertentu (Mia Lasmi Wardiyah, 2017:78).

Untuk melihat kondisi keuangan suatu perusahaan, maka salah satu faktor penentu berhasil tidaknya perusahaan yaitu dalam mengelola modal kerjanya. Modal kerja merupakan suatu indikator yang sangat penting bagi perusahaan. Dengan modal kerja, kegiatan operasi perusahaan akan berjalan dengan baik dan juga dapat diperlukan untuk memelihara perkembangan perusahaan secara berkelanjutan. Modal kerja akan dibutuhkan bagi perusahaan yang ingin mempertahankan eksistensinya. Disamping itu pula perusahaan perlu melakukan pengelolaan modal dengan baik agar tersedia modal yang cukup dalam melaksanakan peningkatan kegiatan operasinya, seperti menambah tenaga kerja, mesin, membayar gaji ataupun dalam perluasan usahanya, serta dapat tercapainya tinggat keuntungan yang optimal maupun kelangsungan hidup perusahaan dapat terjamin.

Pengelolaan modal kerja yang baik adalah salah satu kunci sukses dalam sebuah usaha untuk terus beraktivitas dalam memproduksi barang maupun jasa. Dengan kondisi modal kerja yang cukup perusahaan beroperasi sesuai dengan kelayakan finansial menurut aktivitas yang ada serta perusahaan tidak mengalami kesulitan keuangan. Apabila perusahaan kekurangan modal kerja untuk meningkatkan produksinya, maka kemungkinan besar akan kehilangan pendapatan dan keuntungan atau akan terjadi kebangkrutan.

Keberhasilan suatu perusahaan tidak hanya dilihat dari modal kerjanya, namun dapat dilihat juga dari bagaimana perusahaan dapat membayar hutang jangka pendeknya. Likuiditas merupakan salah satu faktor yang menentukan sukses tidaknya suatu perusahaan. Likuiditas dapat menggambarkan tentang keadaan profitabilitas suatu perusahaan, karena untuk kelangsungan hidupnya, perusahaan harus berada dalam kondisi yang menguntungkan atau profitable. Tanpa adanya keuntungan, akan sangat sulit perusahaan dalam upaya menarik modal dari pihak luar.

Adapun penelitian terdahulu yang telah dilakukan oleh Ade Heri Irawan (2011) dalam skripsinya yang berjudul Analisis Laporan Keuangan Atas Modal Kerja Untuk Menilai Kinerja Koperasi Karyawan Gunung Garuda Metal PT. Gunung Steel Group menyimpulkan bahwa pada tahun 2008 dan 2009 modal kerja mengalami peningkatan yang berakibat laba koperasi semakin menurun karena adanya dana yang 
tidak produktif. Pada tahun 2010 modal kerja mengalami penurunan yang berakibat terhadap efisiensi operasi koperasi sehingga dapat meningkatkan laba koperasi. Selain itu, Vayya Desy Agustina (2015) melakukan penelitian yang berjudul Pengelolaan Modal Kerja Yang Efektif Untuk Meningkatkan Profitabilitas. Hasil penelitian ini menunjukkan bahwa Kinerja perusahaan mengalami penurunan yang terlihat dari menurunnya Receivabel Turnover sehingga menyebabkan terlambatnya waktu pengumpulan piutang. Net Working Capital Turnover juga mengalami penurunan yang menandakan bahwa modal kerja belum mampu berputar secara optimal sehingga berdampak pada penurunan tingkat profitabilitas. Sedangkan Aulia Rahma (2011) dalam skripsinya Pengaruh Manajemen Modal Kerja terhadap Profitabilitas Perusahaan (Studi pada Perusahaan Manufaktur PMA dan PMDN yang Terdapat di BEI 2004-2008). Hasil penelitian ini menunjukkan perputaran modal kerja mempunyai pengaruh negatif yang signifikan terhadap ROI, perputaran kas berpengaruh positif terhadap profitabilitas (ROI), perputaran persediaan tidak mempunyai pengaruh yang signifikan terhadap ROI. Sedangkan Abdul Malik Firmansyah (2015) dalam skripsinya Peningkatan Profitabilitas Melalui Efisiensi Penggunaan Modal Kerja Pada UD Batik Sayu Wiwit Banyuwangi menyimpulkan bahwa modal kerja pada UD Sayu Wiwit Banyuwangi sudah efisien karena terjadi peningkatan setiap tahunnya. Dengan efisiensi modal kerja juga dapat meningkatkan tingkat profitabilitas. Adapun Septy Ragaly (2010) melakukan penelitian Analisis Efisiensi dan Efektivitas Manajemen Modal Kerja Dalam Meningkatkan Profitabilitas Pada Perusahaan Kosmetik Yang Terdaftar Di BEI. Hasil penelitian menunjukkan bahwa dilihat dari perkembangan rasio likuiditas selama tahun 2006-2008 perusahaan yang cenderung efisien adalah PT. Mustika Ratu
Tbk, dilihat dari rata-rata rasio perusahaan yang menunjukkan efisien adalah PT. Mandom Indonesia Tbk, dilihat dari perkembangan rasio aktivitas tahun 20062008 perusahaan yang menunjukkan efektif adalah PT. Unilever Indonesia Tbk, dilihat dari perkembangan profitabilitas perusahaan yang memiliki kemampuan meningkatkan laba adalah PT. Mustika Ratu Tbk meskipun relatif kecil.

Mengingat bahwa pengelolaan modal kerja merupakan hal yang sangat penting dan berperan dalam menunjang keberhasilan perusahaan, untuk itu penulis tertarik untuk menganalisis laporan keuangan perusahaan.

\section{METODE PENELITIAN}

\section{Desain Penelitian}

Dalam melakukan suatu penelitian sangat perlu dilakukan perencanaan penelitian agar penelitian yang dilakukan dapat berjalan dengan baik dan sistematis.

Desain penelitian merupakan semua proses penelitian yang dilakukan oleh penulis dalam melaksanakan penelitian mulai dari perencanaan sampai dengan pelaksanaan penelitian yang dilakukan dengan cara memilih, mengumpulkan dan menganalisis data yang diteliti pada waktu tertentu.

\section{Definisi Operasionalisasi Variabel}

Definisi operasional adalah suatu definisi yang diberikan kepada suatu variabel atau konstark dengan cara memberikan arti, atau menspesifikasikan kegiatan, atau memberikan suatau operasional yang diperlukan untuk mengukur konstrak atau variable tersebut.

Dalam ilmu ekstanta (natura) variable yang digunakan umumnya nyata dan mudah dimengerti, diraba dan dilihat, sehingga kurang menimbulkan keraguraguan akan makna dan ukurannya

(H. Soepeno:2013). 
Operasioanalisasi variabel diperlukan untuk menentukan jenis, indikator, serta skala dari variabel-variabel yang terkait dalam penelitian, maka variabel-variabel yang terkait dalam penelitian ini adalah :

\section{Variabel independen}

Variable yang mempengaruhi atau yang menjadi sebab perubahannya atau timbulnya variable dependen. Data yang menjadi variabel bebas (X) adalah Analisis Laporan Keuangan.

\section{Variable Dependen}

Variable yang dipengaruhi atau akibat, karena adanya variable bebas. Data yang menjadi variabel terikat (Y1) Keberhasilan Mengelola Modal Kerja.

Tabel 1.2

Operasionalisasi Variabel

\begin{tabular}{|c|c|c|}
\hline $\begin{array}{l}\text { Variabel/Sub } \\
\text { Variabel }\end{array}$ & Indikator & Skala/Ukuran \\
\hline $\begin{array}{l}\text { Analisis Laporan } \\
\text { Keuangan }\end{array}$ & $\begin{array}{ll}\text { 1. } & \text { Rasio } \\
& \text { Profitabilitas } \\
\text { 2. } & \text { Rasio } \\
& \text { Likuiditas } \\
\text { 3. } & \text { Rasio } \\
& \text { Aktktivitas }\end{array}$ & Rasio \\
\hline $\begin{array}{l}\text { Keberhasilan } \\
\text { Mengelola } \\
\text { Modal Kerja }\end{array}$ & $\begin{array}{l}\text { Metode Altman Z- } \\
\text { Score }\end{array}$ & Rasio \\
\hline
\end{tabular}

Jenis Data

\section{Data Kualitatif}

Data Kulitatif adalah data yang tidak dapat dihitung atau diukur secara matematis. Data kualitatif dalam penulisan penelitian ini adalah tinjauan umum objek penelitian seperti sejarah dan kegiatan perusahaan, struktur organisasi, dan job description.

\section{Data Kuantitatif}

Data Kuantitatif adalah jenis data yang biasanya dinyatakan dengan satuan angkaangka, baik diperoleh dari sumber aslinya maupun diperoleh melalui hasil pengukuran statistik menggunakan teknik-teknik statistik yang telah dilakukan sebelumnya.

\section{Sumber Data}

\section{Data Primer}

Data primer yaitu data-data yang diperoleh langsung dari perusahaan atau sumber aslinya berupa hasil wawancara langsung dengan subjek penelitian.

\section{Data Sekunder}

Data sekunder yaitu data yang diperoleh seorang peneliti secara tidak langsung dari objeknya, tetapi melalui sumber lain, baik secara lisan maupun tulisan.

\section{Pengumpulan Data}

Dalam melaksanakan penelitian ini, metode yang digunakan untuk memperoleh data guna menunjang penelitian ini diantaranya:

\section{Studi Pustaka}

Mengumpulkan informasi atau datadata terkait dengan penelitian dari buku, catatan - catatan materi perkuliahan, jurnal, karya tulis atau bahan tulisan lainnya dan media lainnya yang berkaitan dengan materi dan permasalahan yang diteliti untuk digunakan sebagai referensi dalam penyusunan ataupun pelaksanaan penelitian itu sendiri. 


\section{Studi Lapangan}

Mengadakan peninjauan langsung keperusahaan untuk mengumpulkan data dan informasi dari data-data perusahaan dengan cara :

\section{a. Observasi}

Pengumpulan data langsung dari tempat penelitian, yaitu mengumpulkan data atau informasi langsung dari tempat atau obyek penelitian.

\section{b. Wawancara}

Salah satu cara untuk memperoleh dan mengumpulkan data dengan cara menanyakan langsung atau bisa disebut dengan melakukan tanya jawab kepada pihak-pihak yang berwenang, dengan maksud mendapatkan informasi tentang permasalahan yang diteliti.

\section{c. Dokumentasi}

Suatu metode pengumpulan data yang dilakukan dengan cara mencatat data - data yang diperlukan, gambaran umum perusahaan, sejarah singkat perusahaan, mengumpulkan data - data lainnya atau mengcopy data dari perusahaan yang relevan dengan keperluan peneliti.

\section{Metode Analisis Data}

Metode analisis yang digunakan dalam penelitian ini adalah dengan menggunakan metode deskriptif yang digunakan untuk mengelola dan menganalisa data-data yang digunakan dalam penelitian ini. Metode deskriptif yang digunakan dalam penelitian ini adalah hubungannya dengan variabel lainnya. Metode deskriptif ini bersifat kualitatif, dan bertujuan untuk menjelaskan secara sistematis, faktual dan akurat dalam mengenai fakta dan karakteristik popular atau hal tertentu.

\section{HASIL DAN PEMBAHASAN}

Analisis Rasio Keuangan

Dalam melakukan analisis rasio keuangan perusahaan, penulis melakukan pengumpulan data perusahaan dan menggunakan data dari laporan keuangan tahunan PT. Catur Sentosa Adiprana Tbk pada tahun 2013-2017. Untuk mengetahui kondisi keuangan perusahaan dalam mengelola modal kerjanya, penulis menggunakan tiga rasio yaitu rasio profitabilitas, rasio likuiditas dan rasio aktivitas.

Rasio Profitabilitas

1. Gross Profit Margin, merupakan rasio yang menggambarkan laba kotor yang dapat dicapai dari jumlah penjualan.

$$
\text { Gross Profit Margin }=\frac{\text { Laba Kotor }}{\text { Penjualan }} \text { X 100\% }
$$

Tabel 4.1

PT. Catur Sentosa Adiprana Tbk Perhitungan Gross Profit Margin

\begin{tabular}{|l|l|l|l|l|}
\hline Tahun & Laba Kotor & Penjualan & $\begin{array}{l}\text { Gross } \\
\text { Profit } \\
\text { Margin }\end{array}$ & $\begin{array}{l}\text { Kenaikan(+) } \\
\text { /Penurunan } \\
(-)\end{array}$ \\
\hline 2013 & 835.335 .435 & 6.438 .746 .703 & $13 \%$ & - \\
\hline 2014 & 931.738 .567 & 7.143 .924 .568 & $13 \%$ & 0 \\
\hline 2015 & 979.155 .839 & $7.284 .517,501$ & $13 \%$ & 0 \\
\hline 2016 & 1.099 .330 .044 & 7.967 .920 .271 & $14 \%$ & $1 \%(+)$ \\
\hline 2017 & 1.332 .996 .936 & 9.639 .478 .866 & $14 \%$ & 0 \\
\hline
\end{tabular}

Sumber : Hasil Pengolahan Data

Dari hasil perhitungan diatas menunjukkan bahwa gross profit margin pada tahun 2013-2015 cenderung dalam keadaan stabil, yaitu sebesar 13\%. Pada tahun 2016 mengalami kenaikan sebesar 
$1 \%$ menjadi 14\%. Sedangkan tahun 2017 kembali stabil sebesar $14 \%$. Kenaikan gross profit margin pada tahun 2016 disebabkan terjadinya peningkatan penjualan diiringi dengan fluktuatifnya laba kotor.

2. Net Profit Margin, merupakan rasio yang digunakan untuk mengukur keuntungan laba bersih perusahaan dari setiap penjualan.

Net Profit Margin $=\frac{\text { Laba Setelah Pajak }}{\text { Penjualan }} \times 100 \%$

\section{Tabel 4.2}

PT. Catur Sentosa Adiprana Tbk Perhitungan Net Profit Margin

\begin{tabular}{|l|l|l|l|l|}
\hline Tahun & $\begin{array}{l}\text { Laba Setelah } \\
\text { Pajak }\end{array}$ & Penjualan & $\begin{array}{l}\text { Net } \\
\text { Profit } \\
\text { Margin }\end{array}$ & $\begin{array}{l}\text { Kenaikan(+) } \\
\text { / Penurunan } \\
(-)\end{array}$ \\
\hline 2013 & 75.880 .191 & 6.438 .746 .703 & $1 \%$ & - \\
\hline 2014 & 114.689 .405 & 7.143 .924 .568 & $2 \%$ & $1 \%(+)$ \\
\hline 2015 & 43.021 .915 & 7.284 .517 .501 & $1 \%$ & $1 \%(-)$ \\
\hline 2016 & 74.636 .924 & 7.967 .920 .271 & $1 \%$ & 0 \\
\hline 2017 & 89.022 .191 & 9.639 .478 .866 & $1 \%$ & 0 \\
\hline
\end{tabular}

Dari hasil perhitungan diatas menunjukkan bahwa net profit margin pada tahun 2013-2015 cenderung fluktuatif. Pada tahun 2013 sebesar 1\%. Sedangkan pada tahun 2014 mengalami kenaikan sebesar $1 \%$ menjadi sebesar 2\%. Pada tahun 2015 mengalami penurunan sebesar $1 \%$ menjadi 1\% sedangkan pada 2016 dan 2017 net profit margin dalam keadaan stabil. Hal tersebut disebabkan laba setelah pajak yang berfluktuatif dan adanya peningkatan pada penjualan.

3. Return On Investment, merupakan rasio yang digunakan untuk mengukur kemampuan dari modal yang diinvestasikan dalam keseluruhan aktiva untuk menghasilkan keuntungan.
$R O I=\frac{\text { Laba Bersih Setelah Pajak }}{\text { Total Aktiva }} \times 100 \%$

Tabel 4.3

PT. Catur Sentosa Adiprana Tbk

Perhitungan Return On Investment

\begin{tabular}{|l|l|l|l|l|}
\hline Tahun & $\begin{array}{l}\text { Laba Bersih } \\
\text { Setelah } \\
\text { Pajak }\end{array}$ & Total Aktiva & ROI & $\begin{array}{l}\text { Kenaikan(+) } \\
\text { / Penurunan } \\
(-)\end{array}$ \\
\hline 2013 & 75.880 .191 & 3.107 .895 .429 & $2,44 \%$ & - \\
\hline 2014 & 114.689 .405 & 3.308 .917 .601 & $3,47 \%$ & $1,03 \%(+)$ \\
\hline 2015 & 43.021 .915 & 3.522 .572 .851 & $1,22 \%$ & $2,25 \%(-)$ \\
\hline 2016 & 74.636 .924 & 4.240 .820 .320 & $1,76 \%$ & $0,54 \%(+)$ \\
\hline 2017 & 89.022 .191 & 5.138 .259 .285 & $1,73 \%$ & $0,03 \%(-)$ \\
\hline
\end{tabular}

Sumber : Hasil Pengolahan Data

Berdasarkan tabel hasil perhitungan

menunjukkan bahwa return on investment yang diperoleh cenderung fluktuatif. Pada tahun 2013 sebesar 2,44\% sedangkan pada tahun 2014 mengalami kenaikan sebesar 1,03\% menjadi 3,47\%. Pada tahun 2015 mengalami penurunan sebesar $2,25 \%$ menjadi $1,22 \%$. Namun pada tahun 2016 mengalami kenaikan kembali sebesar $0,54 \%$ menjadi $1,76 \%$. Sedangkan tahun 2017 kembali mengalami penurunan sebesar $0,03 \%$ menjadi $1,73 \%$. Dari perhitungan diatas menunjukkan return on investmen pada tahun 2015 lebih kecil dibandingkan dengan tahun 2013, 2014, 2016 dan 2017. Hal ini menunjukkan pengelolaan aktiva masih belum efektif. Perusahaan harus meningkatkan pengelolaan total aset secara lebih efektif agar dapat memperoleh return on investment lebih besar dari tahun 2014 sebesar 3,47\%.

4. Return On Equity, merupakan rasio yang digunakan untuk mengukur kemampuan dari modal sendiri agar menghasilkan keuntungan bagi seluruh pemegang saham, baik saham biasa maupun saham preferen. 
Judul artikel menggunakan Cambria 10 Italic rata kanan

$$
R O E=\frac{\text { Laba Setelah Pajak }}{\text { Modal }} \times 100 \%
$$

Tabel 4.4

PT. Catur Sentosa Adiprana Tbk Perhitungan Return On Equity

\begin{tabular}{|l|l|l|l|l|}
\hline Tahun & $\begin{array}{l}\text { Laba } \\
\text { Setelah } \\
\text { Pajak }\end{array}$ & Modal & ROE & $\begin{array}{l}\text { Kenaikan(+) } \\
/ \text { Penurunan } \\
(-)\end{array}$ \\
\hline 2013 & 75.880 .191 & 716.874 .227 & $10,58 \%$ & - \\
\hline 2014 & 114.689 .405 & 818.877 .777 & $14,01 \%$ & $3,43 \%(+)$ \\
\hline 2015 & 43.021 .915 & 853.518 .984 & $5,04 \%$ & $8,97 \%(-)$ \\
\hline 2016 & 74.636 .924 & 1.411 .774 .313 & $5,29 \%$ & $0,25 \%(+)$ \\
\hline 2017 & 89.022 .191 & 1.525 .276 .979 & $5,84 \%$ & $0,55 \%(+)$ \\
\hline \multicolumn{5}{|c|}{ Sumber : Hasil Pengolahan Data } \\
\hline
\end{tabular}

Berdasarkan tabel diatas menunjukkan bahwa return on equity yang diperoleh pada tahun 2013-2017 cenderung fluktuatif. Pada tahun 2013 yaitu sebesar 10,58\% sedangkan pada tahun 2014 mengalami kenaikan sebesar 3,43\% menjadi $14,01 \%$. Namun pada tahun 2015 mengalami penurunan sebesar $8,97 \%$ menjadi $5,04 \%$. Sedangkan tahun 2016 dan 2017 mengalami kenaikan kembali masingmasing sebesar $0,25 \%$ menjadi $5,29 \%$ untuk tahun 2016 dan $0,55 \%$ menjadi $5,84 \%$ untuk tahun 2017 . Return on equity pada tahun 2015 lebih kecil dibandingkan dengan tahun 2013, 2014, 2016 dan 2017 dikarenakan laba bersih sesudah pajak berfluktuatif dan terjadinya peningkatan modal kerja pada setiap tahunnya. Perusahaan perlu mengelola modal kerja lebih efektif agar memperoleh return on equity lebih besar dari tahun 2014 .

\section{Rasio Likuiditas}

1. Cash Ratio (Rasio Kas), merupakan rasio yang digunakan untuk mengukur kemampuan perusahaan membayar kewajiban lancarnya dengan menggunakan kas atau setara kas.
Cash Ratio $=\frac{\text { Kas }+ \text { Efek }}{\text { Hutang Lancar }} \times 100 \%$

Tabel 4.5

PT. Catur Sentosa Adiprana Tbk Perhitungan Cash Ratio

\begin{tabular}{|l|l|l|l|l|}
\hline Tahun & Kas+Efek & $\begin{array}{l}\text { Hutang } \\
\text { Lancar }\end{array}$ & $\begin{array}{l}\text { Cash } \\
\text { Ratio }\end{array}$ & $\begin{array}{l}\text { Kenaikan(+) } \\
\text { / Penurunan } \\
(-)\end{array}$ \\
\hline 2013 & 57.234 .966 & 2.110 .833 .501 & $2,7 \%$ & - \\
\hline 2014 & 51.121 .154 & 2.252 .049 .932 & $2,3 \%$ & $0,4 \%(-)$ \\
\hline 2015 & 63.048 .142 & 2.345 .213 .308 & $2,69 \%$ & $0,39 \%(+)$ \\
\hline 2016 & 71.942 .498 & 2.492 .613 .396 & $2,89 \%$ & $0,2 \%(+)$ \\
\hline 2017 & 90.495 .048 & 3.159 .792 .330 & $2,86 \%$ & $0,03 \%(-)$ \\
\hline
\end{tabular}

Sumber : Hasil Pengolahan Data

Dari tabel diatas menunjukkan bahwa cash ratio cenderung fluktuatif. Pada tahun 2013 sebesar 2,7\% sedangkan pada tahun 2014 mengalami penurunan sebesar 0,4 menjadi 2,3\%. Pada tahun 2015 mengalami kenaikan sebesar 0,39\% menjadi 2,69\% dan tahun 2016 mengalami kenaikan kembali sebesar $0,2 \%$ menjadi $2,89 \%$. Sedangkan pada tahun 2017 mengalami penurunan kembali sebesar $0,03 \%$ menjadi $2,86 \%$. Jika dilihat dari tahun 2015 dan 2016 rasio kas dapat dikatakan cukup baik dari tahun 2013, 2014 dan 2017 dalam membayar kewajiban dengan menggunakan aktiva lancarnya.

2. Quick Ratio (Rasio Cepat), merupakan rasio yang menunjukkan kemampuan perusahaan dalam memenuhi atau membayar kewajiban lancarnya dengan aktiva lancar tanpa memperhitungkan nilai persediaan.

$$
\text { Quick Ratio }=\frac{\text { Aktiva Lancar }- \text { Persediaan }}{\text { Hutang Lancar }}
$$


Tabel 4.6

PT. Catur Sentosa Adiprana Tbk Perhitungan Quick Ratio

\begin{tabular}{|c|c|c|c|c|c|}
\hline & \multicolumn{5}{|c|}{ Perhitungan Quick Ratio } \\
\hline Tahun & $\begin{array}{l}\text { Aktiva } \\
\text { Lancar }\end{array}$ & Persediaan & $\begin{array}{l}\text { Hutang } \\
\text { Lancar }\end{array}$ & $\begin{array}{l}\text { Quick } \\
\text { Ratio }\end{array}$ & $\begin{array}{l}\text { Kenaikan(+) } \\
\text { / Penurunan } \\
(-)\end{array}$ \\
\hline 2013 & $\begin{array}{l}2.265 .88 \\
0.925\end{array}$ & $\begin{array}{l}1.090 .835 .3 \\
16\end{array}$ & $\begin{array}{l}2.110 .833 .5 \\
01\end{array}$ & 0,56 & - \\
\hline 2014 & $\begin{array}{l}2.541 .77 \\
6.452\end{array}$ & $\begin{array}{l}1.242 .866 .5 \\
82\end{array}$ & $\begin{array}{l}2.252 .049 .9 \\
32\end{array}$ & 0,58 & $0,02(+)$ \\
\hline 2015 & $\begin{array}{l}2.554 .32 \\
5.036\end{array}$ & $\begin{array}{l}1.351 .860 .4 \\
83\end{array}$ & $\begin{array}{l}2.345 .213 .3 \\
08\end{array}$ & 0,51 & $0,07(-)$ \\
\hline 2016 & $\begin{array}{l}3.134 .57 \\
6.683\end{array}$ & $\begin{array}{l}1.636 .601 .8 \\
43\end{array}$ & $\begin{array}{l}2.492 .613 .3 \\
96\end{array}$ & 0,6 & $0,09(+)$ \\
\hline 2017 & $\begin{array}{l}3.662 .49 \\
9.520\end{array}$ & $\begin{array}{l}1.769 .543 .9 \\
18\end{array}$ & $\begin{array}{l}3.159 .792 .3 \\
30\end{array}$ & 0,6 & 0 \\
\hline
\end{tabular}

Sumber : Hasil Pengolahan Data

Berdasarkan tabel diatas quick ratio pada tahun 2013-2017 cenderung fluktuatif. Pada tahun 2013 sebesar 0,56 kali sedangkan pada tahun 2014 mengalami kenaikan sebesar 0,02 menjadi 0,58 kali. Pada tahun 2015 mengalami penurunan yaitu sebesar 0,07 menjadi 0,51 kali. Namun pada tahun 2016 mengalami kenaikan kembali sebesar 0.09 menjadi 0, 6 kali. Sedangkan quick ratio tahun 2017 dalam kondisi stabil sebesar 0,6 kali. Dapat diketahui bahwa quick ratio tahun 2013 sampai 2017 dapat dikatakan cukup baik karena pada setiap tahunnya cenderung meningkat.

3. Current Ratio (Rasio Lancar), merupakan rasio untuk mengukur kemampuan perusahaan dalam membayar kewajiban jangka pendek yang segera jatuh tempo pada saat ditagih secara keseluruhan.

Tabel 4.7

PT. Catur Sentosa Adiprana Tbk Perhitungan Current Ratio

\begin{tabular}{|l|l|l|l|l|}
\hline Tahun & Aktiva Lancar & $\begin{array}{l}\text { Hutang } \\
\text { Lancar }\end{array}$ & $\begin{array}{l}\text { Current } \\
\text { Ratio }\end{array}$ & $\begin{array}{l}\text { Kenaikan(+) } \\
\text { / Penurunan } \\
(-)\end{array}$ \\
\hline 2013 & 2.265 .880 .925 & 2.110 .833 .501 & 1,07 & - \\
\hline 2014 & 2.541 .776 .452 & 2.252 .049 .932 & 1,12 & $0,05(+)$ \\
\hline 2015 & 2.554 .325 .036 & 2.345 .213 .308 & 1,08 & $0,04(-)$ \\
\hline 2016 & 3.134 .576 .683 & 2.492 .613 .396 & 1,26 & $0,18(+)$ \\
\hline 2017 & 3.662 .499 .520 & 3.159 .792 .330 & 1,16 & $0,10(-)$ \\
\hline
\end{tabular}

Sumber : Hasil Pengolahan Data

Berdasarkan tabel diatas current ratio pada tahun 2013-2017 cenderung fluktuatif. Pada tahun 2013 sebesar 1,07 kali, artinya jumlah aktiva lancar sebanyak 1,07 kali hutang lancar, atau setiap 1 rupiah hutang lancar dijamin oleh Rp1,07 harta lancar atau 1,07:1 antara aktiva lancar dengan hutang lancar. Sedangkan pada tahun 2014 mengalami kenaikan sebesar 0,05 menjadi 1,12 kali. Artinya jumlah aktiva lancar sebanyak 1,12 kali hutang lancar, atau setiap 1 rupiah hutang lancar dijamin oleh Rp1,12 harta lancar atau 1,12:1 antara aktiva lancar dengan hutang lancar. Pada tahun 2015 mengalami penurunan yaitu sebesar 0,04 menjadi 1,08 kali. Artinya jumlah aktiva lancar sebanyak 1,08 kali hutang lancar, atau setiap 1 rupiah hutang lancar dijamin oleh Rp1,08 harta lancar atau 1,08:1 antara aktiva lancar dengan hutang lancar. Namun pada tahun 2016 mengalami kenaikan kembali sebesar 0,18 menjadi 1,26 kali. Artinya jumlah aktiva lancar sebanyak 1,26 kali hutang lancar, atau setiap 1 rupiah hutang lancar dijamin oleh Rp1,26 harta lancar atau 1,26:1 antara aktiva lancar dengan hutang lancar. Sedangkan tahun 2017 kembali mengalami penurunan sebesar 0.10 menjadi 1,16 kali. Artinya jumlah aktiva lancar sebanyak 1,16 kali hutang lancar, atau setiap 1 rupiah hutang lancar dijamin oleh Rp1,16 harta lancar atau 1,16:1 antara 
aktiva lancar dengan hutang lancar.

\subsubsection{Rasio Aktivitas}

1. Perputaran Aktiva (Total Assets Turn Over), merupakan rasio yang digunakan untuk mengukur perputaran semua aktiva yang dimiliki perusahaan dan mengukur berapa jumlah penjualan yang diperoleh dari tiap rupiah aktiva.

Total Assets Turn Over $=\frac{\text { Penjualan }}{\text { Total Aktiva }}$

Tabel 4.8

PT. Catur Sentosa Adiprana Tbk

Perhitungan Total Assets Turn Over

\begin{tabular}{|l|l|l|l|l|}
\hline $\begin{array}{l}\text { Tahu } \\
\mathrm{n}\end{array}$ & Penjualan & Total Aktiva & $\begin{array}{l}\text { Total } \\
\text { Assets } \\
\text { Turn } \\
\text { Over }\end{array}$ & $\begin{array}{l}\text { Kenaikan(+) / } \\
\text { Penurunan (-) }\end{array}$ \\
\hline 2013 & 6.438 .746 .703 & 3.107 .895 .429 & 2,07 & - \\
\hline 2014 & 7.143 .924 .568 & 3.308 .917 .601 & 2,16 & $0,09(+)$ \\
\hline 2015 & $7.284 .517,501$ & 3.522 .572 .851 & 2,07 & $0,09(-)$ \\
\hline 2016 & 7.967 .920 .271 & 4.240 .820 .320 & 1,88 & $0,19(-)$ \\
\hline 2017 & 9.639 .478 .866 & 5.138 .259 .285 & 1,88 & 0 \\
\hline \multicolumn{5}{|c|}{ Sumber : Hasil Pengolahan Data } \\
\hline
\end{tabular}

Berdasarkan tabel diatas total assets turn over pada tahun 2013-2017 cenderung fluktuatif. Pada tahun 2013 sebesar 2,07 kali, artinya setiap Rp1,00 aktiva tetap dapat menghasilkan $\mathrm{Rp2,07}$ penjualan. Pada tahun 2014 mengalami kenaikan sebesar 0,09 menjadi 2,16 kali, artinya setiap Rp1,00 aktiva tetap dapat menghasilkan Rp2,16 penjualan. Pada tahun 2015 mengalami penurunan yaitu sebesar 0,09 menjadi 2,07 kali, artinya setiap Rp1,00 aktiva tetap dapat menghasilkan Rp2,16 penjualan. Pada tahun 2016 mengalami penurunan sebesar 0,19 menjadi 1,88 kali, artinya setiap Rp1,00 aktiva tetap dapat menghasilkan Rp1,88 penjualan. Sedangkan quick ratio tahun 2017 dalam kondisi stabil sebesar 1,88, artinya setiap Rp1,00 aktiva tetap dapat menghasilkan $\mathrm{Rp} 1,88$ penjualan. Kondisi perusahaan pada tahun 2015 sampai tahun 2016 tidak efektif karena terjadi penurunan rasio. Perusahaan diharapkan meningkatkan lagi penjualannya atau mengurangi sebagian aktiva yang kurang produktif.

2. Perputaran Modal Kerja (Working Capital Turn Over), merupakan rasio yang digunakan untuk mengukur atau menilai keefektifan modal kerja perusahaan selama periode tertentu.

Working Capital Turn Over $=\frac{\text { Penjualan Bersih }}{\text { Aktiva Lancar }- \text { Hutang Lancar }}$

Tabel 4.9

PT. Catur Sentosa Adiprana Tbk Perhitungan Working Capital Turn Over

\begin{tabular}{|c|c|c|c|c|c|}
\hline & & & & & \\
\hline Tahun & $\begin{array}{l}\text { Penjualan } \\
\text { Bersih }\end{array}$ & $\begin{array}{l}\text { Aktiva } \\
\text { Lancar }\end{array}$ & $\begin{array}{l}\text { Hutang } \\
\text { Lancar }\end{array}$ & $\begin{array}{l}\text { Working } \\
\text { Capital } \\
\text { Turn } \\
\text { Over }\end{array}$ & $\begin{array}{l}\text { Kenaikan( } \\
+) \\
\text { Penurunan } \\
(-)\end{array}$ \\
\hline 2013 & $\begin{array}{l}6.438 .746 . \\
703\end{array}$ & $\begin{array}{l}2.265 .8 \\
80.925\end{array}$ & $\begin{array}{l}2.110 .833 \\
.501\end{array}$ & 41,53 & - \\
\hline 2014 & $\begin{array}{l}7.143 .924 . \\
568\end{array}$ & $\begin{array}{l}2.541 .7 \\
76.452\end{array}$ & $\begin{array}{l}2.252 .049 \\
.932\end{array}$ & 24,66 & $16,87(-)$ \\
\hline 2015 & $\begin{array}{l}\text { 7.284.517, } \\
501\end{array}$ & $\begin{array}{l}2.554 .3 \\
25.036\end{array}$ & $\begin{array}{l}2.345 .213 \\
.308\end{array}$ & 34,84 & $10,18(+)$ \\
\hline 2016 & $\begin{array}{l}7.967 .920 . \\
271\end{array}$ & $\begin{array}{l}3.134 .5 \\
76.683\end{array}$ & $\begin{array}{l}2.492 .613 \\
.396\end{array}$ & 12,41 & $22,43(-)$ \\
\hline 2017 & $\begin{array}{l}9.639 .478 . \\
866\end{array}$ & $\begin{array}{l}3.662 .4 \\
99.520\end{array}$ & $\begin{array}{l}3.159 .792 \\
.330\end{array}$ & 19,18 & $6,77(+)$ \\
\hline
\end{tabular}

Sumber : Hasil Pengolahan Data

Berdasarkan tabel diatas working capital turn over pada tahun 2013-2017 cenderung fluktuatif. Pada tahun 2013 sebesar 41,53 kali, artinya setiap Rp1,00 modal kerja dapat menghasilkan Rp41,53 penjualan. Pada tahun 2014 mengalami penurunan 
sebesar 16,87 menjadi 24,66 kali, artinya setiap Rp1,00 modal kerja dapat menghasilkan Rp24,66 penjualan. Pada tahun 2015 mengalami kenaikan sebesar 10,18 menjadi 12,41 kali, artinya setiap Rp1,00 modal kerja dapat menghasilkan Rp12,41 penjualan. Pada tahun 2016 mengalami penurunan kembali sebesar 22,43, menjadi 12,41 kali, artinya setiap Rp1,00 modal kerja dapat menghasilkan Rp12,41 penjualan. Sedangkan quick ratio tahun 2017 mengalami kenaikan kembali sebesar 6,77 menjadi sebesar 19,18 kali. Pada tahun 2013 ke tahun 2014 dan tahun 2015 ke tahun 2016 perusahaan mengalami kondisi penurunan dalam perputaran modal kerja dikarenakan perusahaan sedang mengalami kelebihan modal kerja. Namun, pada tahun 2014 ke tahun 2015 dan 2016 ke tahun 2017 perusahaan mengalami kenaikan rasio perputaran modal kerja, hal ini menunjukkan adanya kemajuan yang diperoleh manajemen.

3. Perputaran Piutang (Receivable Turn Over), merupakan rasio yang digunakan untuk mengukur berapa lama penagihan piutang selama satu periode atau berapa kali dana yang ditanam dalam piutang ini berputar dalam satu periode. Semakin tinggi rasio menunjukkan bahwa modal kerja yang ditanamkan dalam piutang semakin rendah.

$$
\text { Receivable Turn Over }=\frac{\text { Penjualan Kredit }}{\text { Rata }- \text { rata Piutang }}
$$

Tabel 4.10

PT. Catur Sentosa Adiprana Tbk Perhitungan Receivable Turn Over

\begin{tabular}{|l|l|l|l|l|}
\hline Tahun & $\begin{array}{l}\text { Penjualan } \\
\text { Kredit }\end{array}$ & $\begin{array}{l}\text { Rata-rata } \\
\text { Piutang }\end{array}$ & $\begin{array}{l}\text { Receivable } \\
\text { Turn Over }\end{array}$ & $\begin{array}{l}\text { Kenaikan(+) } \\
\text { / Penurunan } \\
(-)\end{array}$ \\
\hline 2013 & 1.001 .080 .592 & 8.799 .524 .805 & 0,11 & - \\
\hline 2014 & 1.139 .410 .757 & 1.070 .205 .675 & 0,06 & $0,05(-)$ \\
\hline 2015 & 1.041 .516 .462 & 1.090 .463 .610 & 0,96 & $0,9(+)$ \\
\hline 2016 & 1.260 .446 .621 & 1.150 .981 .542 & 1,09 & $0,13(+)$ \\
\hline 2017 & 1.579 .965 .731 & 1.420 .206 .176 & 1,11 & $0,02(+)$ \\
\hline
\end{tabular}

Sumber : Hasil Pengolahan Data

Berdasarkan tabel diatas receivable turn over pada tahun 2013-2017 cenderung meningkat. Pada tahun 2013 sebesar 0,11 kali dibandingkan penjualan. Pada tahun 2014 mengalami penurunan sebesar 0,05 menjadi 0,06 kali. Pada tahun 2015 mengalami kenaikan sebesar 0,9 menjadi 0,96 kali. Namun pada tahun 2016 mengalami kenaikan kembali sebesar 0,13 menjadi 1,09 kali. Sedangkan pada tahun 2017 mengalami kenaikan sebesar 0,02 menjadi 1,11 kali. Pada tahun 2014-2017 terjadinya peningkatan pada rasio perputaran piutang. Hal ini dapat dikatakan bahwa semakin tinggi rasio menunjukkan bahwa modal kerja yang ditanamkan dalam piutang semakin rendah dan kondisi perusahaan semakin baik.

4. Perputaran Persediaan (Inventory Turn Over), merupakan rasio yang digunakan untuk mengukur berapa kali dana yang ditanam dalam persediaan ini berputar dalam suatu periode.

$$
\text { Inventory Turn Over }=\frac{\text { Harga Pokok Penjualan }}{\text { Rata }- \text { rata Persediaan }}
$$

Tabel 4.11

PT. Catur Sentosa Adiprana Tbk

Perhitungan Inventory Turn Over

\begin{tabular}{|l|l|l|l|l|}
\hline \multicolumn{3}{|c|}{ Perhitungan Inventory Turn Over } \\
\hline \multirow{2}{*}{ Tahun } & $\begin{array}{l}\text { Harga Pokok } \\
\text { Penjualan }\end{array}$ & $\begin{array}{l}\text { Rata-rata } \\
\text { Persediaan } \\
\text { tory } \\
\text { Turn } \\
\text { Over }\end{array}$ & $\begin{array}{l}\text { Kenaika } \\
\mathrm{n}(+) \quad / \\
\text { Penurun } \\
\text { an (-) }\end{array}$ \\
\hline 2013 & 5.485 .821 .810 & $969.981 .117,5$ & 5,66 & - \\
\hline
\end{tabular}




\begin{tabular}{|l|l|l|l|l|}
\hline 2014 & 6.066 .148 .784 & 1.166 .850 .949 & 5,2 & $0,46(-)$ \\
\hline 2015 & 6.138 .677 .234 & 1.297 .363 .533 & 4,73 & $0,47(-)$ \\
\hline 2016 & 6.665 .558 .581 & 1.494 .231 .163 & 4,46 & $0,27(-)$ \\
\hline 2017 & 8.009 .147 .562 & 1.703 .072 .881 & 4,7 & $0,24(+)$ \\
\hline
\end{tabular}

Sumber : Hasil Pengolahan Data

Berdasarkan tabel diatas inventory turn over pada tahun 2013-2017 cenderung mengalami penurunan. Pada tahun 2013 sebesar 5,66 kali dibandingkan penjualan. Rasio ini menunjukkan 5,66 kali persediaan barang dagangan diganti dalam satu tahun. Pada tahun 2014 mengalami penurunan sebesar 0,46 menjadi 5,52 kali. Maka, rasio ini menunjukkan 5,52 kali persediaan barang dagangan diganti dalam satu tahun. Pada tahun 2015 mengalami penurunan sebesar 0,47 menjadi 4,73 kali. Hal ini menunjukkan 4,73 kali persediaan barang dagangan diganti dalam satu tahun. Pada tahun 2016 mengalami penurunan sebesar 0,27 menjadi 4,46 kali. Maka, rasio ini menunjukkan 4,46 kali persediaan barang dagangan diganti dalam satu tahun. Sedangkan pada tahun 2017 mengalami kenaikan sebesar 0,24 menjadi 4,7 kali. Rasio ini menunjukkan 4,7 kali persediaan barang dagangan diganti dalam satu tahun. Dari tabel diatas dapat dilihat penurunan rasio perputaran persediaan dari tahun 2013 sampai tahun 2016, hal tersebut dapat dikatakan perusahaan bekerja kurang efisien atau tidak produktif dan banyak barang persediaan yang menumpuk.

4.2 Analisis Indikator Kebangkrutan dengan Menggunakan Metode Altman Models

Dari beberapa varian Altman Z-Score, model Z-Score yang digunakan yaitu ZScore asli, karena perusahaan yang diteliti adalah perusahaan yang akan penulis teliti adalah perusahaan publik dan manufaktur. Z-Score asli pertama kali dirumuskan oleh Altman dengan sampel yang diambil dari perusahaan manufaktur publik yang berlokasi di Amerika, dirumuskan tahun 1968 dengan jumlah sampel 66 perusahaan yang terdiri dari 33 perusahaan bangkrut dan 33 perusahaan tidak bangkrut.

Rumus Z-Score asli yang digunakan yaitu :

\section{$\mathrm{Z}=0,012 \mathrm{X} 1+0,014 \mathrm{X} 2+0,033 \mathrm{X} 3+$ $0,006 \mathrm{X} 4+0,999 \times 5$}

Menurut Bambang Hermanto dan Mulyo Agung dalam bukunya Analisis Laporan Keuangan (2015:241) berikut ini adalah fungsi atau peranan diskriminan yaitu sebagai berikut :

\section{1. $\mathrm{X} 1=$ Modal Kerja/Total Aset}

Rasio ini menunjukkan perusahaan untuk menghasilkan modal kerja bersih dari keseluruhan total aset yang dimiliki. Modal kerja bersih yang negatif kemungkinan besar akan menghadapi masalah dalam menutupi kewajiban jangka pendek karena tidak tersedianya aktiva lancar yang cukup untuk menutupi kewajiban tersebut. Sebaliknya, baik dengan modal kerja bersih yang positif jarang sekali menghadapi kesulitan dalam melunasi kewajibannya.

2. $\mathrm{X} 2=$ Laba Ditahan/Total Aset Rasio ini menunjukkan kemampuan perusahaan untuk menghasilkan laba ditahan dari total aset perusahaan. Laba ditahan merupakan laba yang tidak dapat dibagikan kepada para pemegang saham. Dengan kata lain laba ditahan menunjukkan berapa banyak pendapatan yang tidak dibayarkan dalam bentuk dividen kepada para pemegang saham. Laba ditahan terjadi karena pemegang saham biasa mengijinkan perusahaan untuk menginvestasikan kembali laba yang tidak didistribusikan sebagai dividen. Dengan demikian laba ditahan yang dilaporkan dalam neraca bukan merupakan kas dan tidak tersedia untuk pembayaran dividen atau yang lain. 
3. $\mathrm{X} 3$ = Laba Sebelum Bunga dan Pajak/Total Aktiva

Rasio ini menunjukkan kemampuan perusahaan untuk menghasilkan laba dari aktiva perusahaan tersebut sebelum pembayaran bunga dan pajak.

4. $\mathrm{X} 4=$ Nilai Pasar Saham/Total Hutang

Rasio ini menunjukkan kemampuan jangka panjang dari suatu perusahaan dan menunjukkan kemampuan perusahaan untuk memenuhi kewajiban-kewajiban dari nilai pasar modal itu sendiri (saham biasa). Nilai pasar ekuitas sendiri diperoleh dengan mengalikan jumlah lembar saham biasa yang beredar dengan harga pasar perlembar saham biasa. Nilqi buku hutang diperoleh dengan menjumlahkan kewajiban lancar dengan kewajiban jangka panjang.

\section{5. $\mathrm{X} 5=$ Penjualan/Total Aktiva}

Rasio ini menunjukkan apakah perusahaan menghasilkan volume bisnis yang dibandingkan investasi dalam total aset. Rasio ini mencerminkan efisiensi manajemen dalam menggunakan keseluruhan aset perusahaan untuk menghasilkan penjualan dan pendapatan laba.

Menurut Altman terdapat angka-angka cut off nilai $\mathrm{Z}$ yang dapat menjelaskan apakah perusahaan akan mengalami kegagalan atau tidak pada masa mendatang dan membaginya kedalam 3 kategori :

\begin{tabular}{|c|c|}
\hline Score & Kondisi \\
\hline$>2,99$ & Tidak Bangkrut \\
\hline $1,81-2,99$ & Daerah Abu-abu \\
\hline$<1,81$ & Bangkrut \\
\hline
\end{tabular}

Analisis diskriminan ini dilakukan untuk memprediksi kebangkrutan suatu perusahaan dengan menganalisis laporan keuangan perusahaan dalam periode dua sampai lima tahun sebelum perusahaan tersebut diprediksi bangkrut.

\section{Perhitungan Untuk Mencari Nilai Z- Score}

$$
\mathrm{X} 1=\frac{\text { Modal Kerja }}{\text { Total Aset }}
$$

Modal Kerja $=$ Total Aktiva Lancar - Total Hutang Lancar

Tabel 4.12

PT. Catur Sentosa Adiprana Tbk Perhitungan Modal Kerja

\begin{tabular}{|c|c|c|c|}
\hline Tahun & $\begin{array}{c}\text { Total Aktiva } \\
\text { Lancar }\end{array}$ & $\begin{array}{c}\text { Total Hutang } \\
\text { Lancar }\end{array}$ & $\begin{array}{c}\text { Modal } \\
\text { Kerja }\end{array}$ \\
\hline 2013 & 2.265 .880 .925 & 2.110 .833 .501 & 155.047 .424 \\
\hline 2014 & 2.541 .776 .452 & 2.252 .049 .932 & 289.726 .520 \\
\hline 2015 & 2.554 .325 .036 & 2.345 .213 .308 & 289.726 .520 \\
\hline 2016 & 3.134 .576 .683 & 2.492 .613 .396 & 641.963 .287 \\
\hline 2017 & 3.662 .499 .520 & 3.159 .792 .330 & 502.707 .190 \\
\hline
\end{tabular}

Sumber : Hasil Pengolahan Data

Tabel 4.13

PT. Catur Sentosa Adiprana Tbk Perhitungan Nilai X1

\begin{tabular}{|c|c|c|c|}
\hline Tahun & $\begin{array}{c}\text { Modal } \\
\text { Kerja }\end{array}$ & Total Aset & $\begin{array}{c}\text { Nilai } \\
\text { X1 }\end{array}$ \\
\hline 2013 & 155.047 .424 & 3.107 .895 .429 & 0,049 \\
\hline 2014 & 289.726 .520 & 3.308 .917 .601 & 0,087 \\
\hline 2015 & 289.726 .520 & 3.522 .572 .851 & 0,082 \\
\hline 2016 & 641.963 .287 & 4.240 .820 .320 & 0,151 \\
\hline 2017 & 502.707 .190 & 5.138 .259 .285 & 0,097 \\
\hline \multicolumn{3}{|c|}{ Sumber : Hasil Pengolahan Data } \\
\hline
\end{tabular}


Judul artikel menggunakan Cambria 10 Italic rata kanan

$\mathrm{X} 2=($ Laba Ditahan $)$

(Total Aset)

Tabel 4.14

PT. Catur Sentosa Adiprana Tbk Perhitungan Nilai X2

\begin{tabular}{|c|c|c|c|}
\hline Tahun & $\begin{array}{c}\text { Laba } \\
\text { Ditahan }\end{array}$ & Total Aset & $\begin{array}{c}\text { Nilai } \\
\text { X2 }\end{array}$ \\
\hline 2013 & 86.012 .823 & 3.107 .895 .429 & 0,027 \\
\hline 2014 & 129.164 .594 & 3.308 .917 .601 & 0,039 \\
\hline 2015 & 57.497 .104 & 3.522 .572 .851 & 0,016 \\
\hline 2016 & 81.874 .519 & 4.240 .820 .320 & 0,019 \\
\hline 2017 & 103.207 .876 & 5.138 .259 .285 & 0,020 \\
\hline
\end{tabular}

Sumber : Hasil Pengolahan Data

$\mathrm{X} 3=\mathrm{EBIT}$

(Total Aset)

Tabel 4.15

PT. Catur Sentosa Adiprana Tbk Perhitungan Nilai X3

\begin{tabular}{|c|c|c|c|}
\hline \multirow{2}{*}{ Tahun } & EBIT & Total Aset & Nilai \\
& & & X3 \\
\hline 2013 & 178.172 .522 & 3.107 .895 .429 & 0,057 \\
\hline 2014 & 241.724 .970 & 3.308 .917 .601 & 0,073 \\
\hline 2015 & 155.059 .722 & 3.522 .572 .851 & 0,044 \\
\hline 2016 & 200.102 .546 & 4.240 .820 .320 & 0,047 \\
\hline 2017 & 223.666 .628 & 5.138 .259 .285 & 0,043 \\
\hline \multicolumn{3}{|c|}{ Sumber : Hasil Pengolahan Data } \\
\hline
\end{tabular}

$\mathrm{X} 4=$ (Nilai Pasar Saham)

(Nilai Buku Hutang)

Tabel 4.16

PT. Catur Sentosa Adiprana Tbk Perhitungan Nilai X4 (Dalam Ribuan Rupiah)

\begin{tabular}{|l|l|l|l|l|l|}
\hline Tahun & $\begin{array}{l}\text { Jumlah } \\
\text { Saham }\end{array}$ & $\begin{array}{l}\text { Harga/ } \\
\text { Lembar } \\
\text { Saham }\end{array}$ & $\begin{array}{l}\text { Nilai } \\
\text { Pasar } \\
\text { Saham }\end{array}$ & $\begin{array}{l}\text { Nilai } \\
\text { Buku } \\
\text { Hutang }\end{array}$ & $\begin{array}{l}\text { Nilai } \\
\text { X4 }\end{array}$ \\
\hline 2013 & $\begin{array}{l}2.895 .03 \\
7.800\end{array}$ & 100 & $\begin{array}{l}289.503 .7 \\
80\end{array}$ & $\begin{array}{l}2.391 .02 \\
1.202\end{array}$ & 0,121 \\
\hline 2014 & $\begin{array}{l}2.895 .03 \\
7.800\end{array}$ & 100 & $\begin{array}{l}289.503 .7 \\
80\end{array}$ & $\begin{array}{l}2.490 .03 \\
9.824\end{array}$ & 0,116 \\
\hline 2015 & $\begin{array}{l}2.895 .03 \\
7.800\end{array}$ & 100 & $\begin{array}{l}289.503 .7 \\
80\end{array}$ & $\begin{array}{l}2.669 .05 \\
3.867\end{array}$ & 0,108 \\
\hline 2016 & $\begin{array}{l}2.895 .03 \\
7.800\end{array}$ & 100 & $\begin{array}{l}289.503 .7 \\
80\end{array}$ & $\begin{array}{l}2.829 .04 \\
6.007\end{array}$ & 0,102 \\
\hline 2017 & $\begin{array}{l}4.053 .05 \\
2.920\end{array}$ & 100 & $\begin{array}{l}405.305 .2 \\
92\end{array}$ & $\begin{array}{l}3.612 .98 \\
2.306\end{array}$ & 0,112 \\
\hline
\end{tabular}

Sumber : Hasil Pengolahan Data

$$
\mathrm{X} 5=\frac{\text { Penjualan }}{\text { Total Aset }}
$$

Tabel 4.17

PT. Catur Sentosa Adiprana Tbk

Perhitungan Nilai X5

\begin{tabular}{|c|c|c|c|}
\hline \multirow{2}{*}{ Tahun } & Penjualan & Total Aset & Nilai \\
& & & X5 \\
\hline 2013 & 6.438 .746 .703 & 3.107 .895 .429 & 2,071 \\
\hline 2014 & 7.143 .924 .568 & 3.308 .917 .601 & 2,158 \\
\hline 2015 & $7.284 .517,501$ & 3.522 .572 .851 & 0,002 \\
\hline 2016 & 7.967 .920 .271 & 4.240 .820 .320 & 1,878 \\
\hline 2017 & 9.639 .478 .866 & 5.138 .259 .285 & 1,876 \\
\hline
\end{tabular}

Sumber : Hasil Pengolahan Data

Tabel 4.18

PT. Catur Sentosa Adiprana Tbk Perhitungan Nilai Z-Score

\begin{tabular}{|c|c|c|c|c|c|c|}
\hline \multirow{2}{*}{ Tahun } & \multicolumn{6}{|c|}{$\begin{array}{c}\text { Z-Score }=0,012 \mathrm{X} 1+0,014 \mathrm{X} 2+0,033 \mathrm{X} 3 \\
+0,006 \mathrm{X} 4+0,999 \mathrm{X} 5\end{array}$} \\
\cline { 2 - 6 } & $\mathrm{X} 1$ & $\mathrm{X} 2$ & $\mathrm{X} 3$ & $\mathrm{X} 4$ & $\mathrm{X} 5$ & Score \\
\hline 2013 & $\begin{array}{c}0,0 \\
49\end{array}$ & 0,027 & 0,057 & 0,121 & 2,071 & 2,05 \\
\hline 2014 & $\begin{array}{c}0,0 \\
87\end{array}$ & 0,039 & 0,073 & 0,116 & 2,158 & 2,14 \\
\hline 2015 & $\begin{array}{c}0,0 \\
82\end{array}$ & 0,016 & 0,044 & 0,108 & 0,002 & 0,01 \\
\hline 2016 & $\begin{array}{c}0,1 \\
51\end{array}$ & 0,019 & 0,047 & 0,102 & 1,878 & 1,86 \\
\hline 2017 & $\begin{array}{c}0,0 \\
97\end{array}$ & 0,020 & 0,043 & 0,112 & 1,876 & 1,86 \\
\hline
\end{tabular}

Sumber : Hasil Pengolahan Data 


$\begin{array}{lcc}\text { Hasil Analisis Indikator } & \text { Kebangkrutan } \\ \text { untuk } & \text { Mengetahui } & \text { Kelangsungan } \\ \text { Perusahaan } & & \end{array}$

Berdasarkan data yang telah dihitung untuk rumus Z-Score asli dapat diketahui kriteria dalam kondisi tidak bangkrut, nilai $\mathrm{Z}$ nya adalah lebih besar dari 2,99. Untuk perusahaan yang keadaannya di dalam daerah wilayah abu-abu nilai $\mathrm{Z}$ nya terletak antara 1,81-2,99. Dan untuk perusahaan yang dapat dikatakan bangkrut nilai $\mathrm{Z}$ nya adalah lebih kecil dari 1,81.

Dari data yang telah dihitung pada tahun 2013 bahwa perusahaan dalam kondisi daerah abu-abu dengan nilai Z-Score 2,05. Berdasarkan rasio keuangan yaitu rasio modal kerja dengan angka 0,049 , rasio laba ditahan dengan angka 0,021, rasio EBIT dengan angka 0,057, rasio pasar saham dengan angka 0,121 , dan rasio penjualan dengan angka sebesar 2,071. Hal yang paling mempengaruhi kebangkrutan adalah nilai rasio modal kerja, rasio laba ditahan dan rasio EBIT dengan hasil terkecil sehingga berdampak pada kondisi keuangan perusahaan.

Pada tahun 2014 hasil perhitungan Z-Score menunjukkan kondisi perusahaan berada pada daerah abu-abu dengan nilai Z-Score sebesar 2,14. Sehingga perusahaan dapat dikatakan belum mengalami kondisi kebangkrutan. Jika dibandingkan dengan tahun 2013 perusahaan mengalami peningkatan nilai Z-Score.

Hasil perhitungan Z-Score pada tahun 2015 mengalami penurunan yang drastis dengan nilai Z-Score sebesar 0,01. Dalam hal ini perusahaan berada dalam kondisi bangkrut. Hal ini disebabkan karena terjadinya penurunan pada laba ditahan dan penurunan penjualan, sehingga kondisi keuangan perusahaan dalam keadaan krisis.

Tahun 2016 hasil perhitungan nilai Z-Score sebesar 1,86 menunjukkan peningkatan dengan kondisi perusahaan berada pada daerah abu-abu. Hal ini disebabkan terjadinya peningkatan pada modal kerja, laba ditahan, EBIT, nilai pasar saham dan penjualan.

Pada tahun 2017 hasil perhitungan nilai ZScore sebesar 1,86 menunjukkan perusahaan dalam kondisi daerah abu-abu. Jika dibandingkan dengan tahun sebelumnnya perusahaan pada tahun ini mengalami penurunan. Sehingga perusahaan harus mampu meningkatkan penjualan agar tidak terancam bangkrut dimasa mendatang.

\section{KESIMPULAN}

Berdasarkan hasil pembahasan tentang analisis laporan keuangan sebagai alat untuk menilai keberhasilan dalam mengelola modal kerja pada PT. Catur Sentosa Adiprana Tbk, maka penulis menarik kesimpulan sebagai berikut:

1. Hasil analisis rasio keuangan pada tahun 2013-2017 dengan menggunakan rasio profitabilitas, dapat dikatakan cukup baik karena perusahaan masih mampu mengelola laba yang diperoleh. Berdasarkan hasil perhitungan rasio likuiditas menunjukkan bahwa perusahaan masih mempunyai dana yang cukup untuk membayar kewajiban jangka pendeknya dengan menggunakan aktiva lancar walaupun hasil perhitungan yang diperoleh berfluktuatif. Jika dilihat dari perhitungan rasio aktivitas kondisi perusahaan pada tahun 2015 sampai tahun 2016 tidak efektif karena terjadi penurunan rasio.

2. Berdasarkan analisis metode ZScore pada tahun 2013-2017 menunjukkan perusahaan berada pada daerah abu-abu yang memungkinkan perusahaan masih bisa meningkatkan kembali kondisi keuangannya. Namun pada tahun 2015 perusahaan mengalami penurunan yang sangat signifikan dan berada pada kondisi bangkrut. Sehingga perusahaan dalam mengelola modal kerjanya masih belum efektif. 


\section{DAFTAR PUSTAKA}

VI. Agustina, Vayya Desy. 2015. Pengelolaan Modal Kerja Yang Efektif Untuk Meningkatkan Profitabilitas. Universitas Brawijaya Malang. Fakultas Ekonomi

VII. Fahmi, Irham. 2013. Analisis Laporan Keuangan. Bandung : Alfabeta

VIII. Firmansyah, Abdul Malik. 2015. Peningkatan Profitabilitas Melalui Efisiensi Penggunaan Modal Kerja Pada UD Batik Sayu Wiwit Banyuwangi. Universitas Negri Islam Maulana Malik. Fakultas Ekonomi

IX. Harjito, D. Agus dan Martono. 2012. Manajemen Keuangan. Edisi Kedua. Jakarta : Ekonisia, FE. UI

X. Harmono. 2011. Manajemen Keuangan. Jakarta : PT. Bumi Aksara

XI. Harmono. 2014. Manajemen Keuangan. Jakarta : PT. Bumi Aksara

XII. Hery. 2015. Analisis Laporan Keuangan. Cetakan Ke-2. Jakarta : PT. Grasindo

XIII. Irawan, Ade Heri. 2011. Analisis Laporan Keuangan Atas Modal Kerja Untuk Menilai Kinerja Koperasi Karyawan Gunung Garuda Metal PT. Gunung Steel Group. Universitas Ibn Khaldun Bogor. Fakultas Ekonomi

XIV. Jumingan. 2014. Analisis Laporan Keuangan. Jakarta : PT. Bumi Aksara

XV. Kasmir. 2014. Analisis Laporan Keuangan. Cetakan ke-7. Jakarta : PT. Rajagrafindo Persada

XVI. Kasmir. 2015. Analisis Laporan Keuangan. Cetakan ke-8. Jakarta : PT. Rajagrafindo Persada

XVII. Prihadi, Toto. 2013. Analisis Laporan Keuangan : Teori dan
Aplikasi. Cetakan ke-3 Jakarta : PPM Manajemen

XVIII. Ragaly, Septy. 2010. Analisis Efisiensi dan Efektivitas Manajemen Modal Kerja Dalam Meningkatkan Profitabilitas Pada Perusahaan Kosmetik Yang Terdaftar Di BEI. Universitas Muhammadiyah Malang. Fakultas Ekonomi

XIX. Rahma, Aulia. 2011. Pengaruh Manajemen Modal Kerja terhadap Profitabilitas Perusahaan (Studi pada Perusahaan Manufaktur PMA dan PMDN yang Terdapat di BEI 2004-2008).

Universitas

Diponegoro. Fakultas Ekonomi

XX. Samryn, L. M. 2014. Pengantar Akuntansi. Cetakan ke-3. Jakarta : PT. Rajagrafindo Persada

XXI. Sugiono. 2014. Metode Penelitian Bisnis. Cetakan ke-18. Bandung : Alfabeta

XXII. Sugiono. 2015. Metode Penelitian Kuantitatif Kualitatif dan $R \& D$. Bandung : Alfabeta

XXIII. Sujarweni, V. Wiratna. 2017. Analisis Laporan Keuangan Teori, Aplikasi, dan Hasil Penelitian. Yogyakarta : Pustaka Baru Press

XXIV. Wardiyah, Mia Lasmi. 2017. Analisis Laporan Keuangan. Cetakan ke-1. Bandung : CV. Pustaka Setia

XXV. https://ilmumanajemenindustri.com/ pengertian-rasio-cepat-quick-ratiorumus-rasio-cepat/ $(6 / 9 / 18, \quad 14: 28$ WIB)

XXVI. http://etheses.uinmalang.ac.id/1512/ (4/918, 19:25 WIB)

XXVII. $\quad$ https://www.google.com/url $?$ sa $=\mathrm{t} \&$ source $=$ web $\&$ rct $=\mathrm{j} \&$ url $=\mathrm{http}:$ //eprints.umm.ac.id/1722/1/ANALI SIS_EFISIENSI_DAN_EFEKTIVI TAS_MANAJEMEN_MODAL_KE RJA_DALAM_MENINGKATKAN PROFITABILITAS_PADA_PER USAHAAN KOSMETIK YANG 
TERDAFTAR DI BEI.pdf\&ved $=2$ ahUKEwj_78mc_d7dAhUMPY8K HUcoBJ0QFjAAegQIBBAB\&usg $=$ AOvVaw0JCyW06wFIdNUuCcWJ $\underline{\mathrm{kPa} 3}(4 / 9 / 18,20: 09 \mathrm{WIB})$

XXVIII. https://www.google.com/url?sa=t \&source=web\&rct=j\&url=http://epri nts.undip.ac.id/28981/1/Skripsi017. pdf\&ved=2ahUKEwiZg7m0_N7dA hVKuo8KHboTDdoQFjABegQICR AB\&usg=AOvVaw3qXDuibsnhHU 8NBFed6wC3\&cshid=1538181722 $719(4 / 9 / 18,21.10 \mathrm{WIB})$

\section{XXIX.}

https://www.google.com/url?sa=t\&s ource $=$ web\&rct=j\&url=http://eprints uny.ac.id/38659/1/skripsi.pdf\&ved $=2$ ahUKEwj6xe78 d7dAhXFqY8K HVczBRMQFjADegQIBxAB\&usg =AOvVaw1W6BDR1405jVPPh O_uYf $(25 / 8 / 18,17: 05$ WIB) 